DOI: 10.7592/methis.v12i15.12123

\title{
Bildungsroman - veel üks Tartu lisandus romaaniteooriasse
}

Liina Lukas

Tartu ülikooli panus rahvusvahelisse romaaniteooriasse ei piirdu ainult Juri Lotmani romaanikäsitlustega. Esimese ja elujõulisima romaaniteooria ja ühtlasi žanrinimetuse pakkus välja Tartu ülikooli õppejõud Karl Morgenstern (1779-1752).

Karl Morgenstern oli 1802. aastal taasrajatud Tartu ülikooli üks esimesi, pikaajalisimaid ja silmapaistvamaid õppejõude, TÜ raamatukogu ja kunstimuuseumi rajaja. 40 aasta vältel õpetas ta Tartus klassikalist filoloogiat, kunstiajalugu, esteetikat, kirjandusajalugu ja - mis toonases ülikoolipraktikas ei olnud sugugi tavaline - pidas Tartus loenguid kaasaegsest kirjandusest. Siin esmakordselt eesti keeles trükivalgust nägev loeng „Kujunemisromaani olemusest“ („Über das Wesen des Bildungsroman“) on peetud Tartus 1819. aastal.

Kujunemisromaani mõistet kasutas Morgenstern tegelikult varemgi. Juba 1803. aastal kavandas ta kirjutist „Kujunemisromaanidest“ („Über Bildungsromane“), vastusena Friedrich von Blankenburgi 1774. aastal ilmunud (õigupoolest üleüldse esimesele saksa) romaaniteooriale „Essee romaanist“ („Versuch über den Roman“), mida Morgenstern sel hetkel tundis veel vaid peakirja järgi. 12/24. detsembril 1810. aastal pidas ta Tartu ülikooli aulas avaliku loengu „Rea filosoofiliste romaanide vaimu ja seose üle“ („Über den Geist und Zusammenhang einer Reihe philosophischen Romane“), mille katkend ilmus 1811. aastal Riia Kirjanduse ja Kunsti Ajalehes (Zeitung für Literatur und Kunst) ning ümbertöötatult 1817. aastal Tartus Morgensterni enda ajakirjas Dörptsche Beyträge für Freunde der Philosophie, Literatur und Kunst.

1819. aastal peetud loeng „Kujunemisromaani olemusest“ ilmus trükis Tartu ajakirjas Inländisches Museum (toimetaja Carl Eduard Raupach) 1820. aastal. Samal aastal pidas ta veel teisegi loengu, võrdleva käsitluse „Kujunemisromaani ajaloost“ („Zur Geschichte des Bildungsroman"), mis ilmub kohe ka trükis ning kordustrükis Raupachi ajakirja jätkuväljaandes Neues Museum der teutschen Provinzen Russlands 1824. aastal. Niisiis, tegu ei ole ühes loengus välgatanud uitmõttega: Morgenstern esitleb Tartu loengutes ja Tartu kirjanduslikteaduslikes ajakirjades oma romaaniteooriat. Nii nagu praegu, oli ka siis perifeersest Tartust raske teaduslikku saavutust laiemasse käibesse tuua ning nii aktualiseeris selle mõiste alles Berliini õpetlane Wilhelm Dilthey 1906. aastal, käsitledes Hölderlini romaani „Hyperion“ oma raamatus „Elamus ja luule“ („Das Erlebnis und die Dichtung“). Sealtpeale on sel olnud romaaniteoorias jätkuvasti konjunktuuri (uuemaid käsitlusi vt Moretti 2000, Kontje 1993, Minden 2010, Jeffers 2005, Mayer 1992, Selbmann 1984, Castle 2006, Summerfield, Downward 2009).

Mis romaan on kujunemisromaan Morgensterni käsitluses? Oleme tõlkinud selle romaaniteoorias enamasti tõlkimata jäetava mõiste eesti keelde just sel kujul, sest levinum aren- 
guromaan oleks Bildungsroman'i vastena sisuliselt eksiteele viiv ning sobiks pigem romaaniteoorias ligilähedases, kuid mitte kattuvas tähenduses kasutusel oleva saksa Entwicklungsroman'i tõlkena. Bildung (sks k 'kujunemine', 'moodustumine', 'moodustis', ka 'haridus', 'haritus'), see Morgensterni ajastu saksa vaimuloo nii oluline mõiste (vrd ka ajastuomaste mõistetega Bildungsgeschichte, Bildungsbürgertum, Bildungsreise), ei ole sugugi taandatav „arenguks“ - lineaarseks ühesuunaliseks progresseeruvaks protsessiks. Algselt religioosse konnotatsiooniga mõiste - pärispatuga koormatud inimese ümberkujunemine Jumala pildi järgi - kujuneb alates Johann Gottfried Herderist saksa ajaloofilosoofiliseks mõisteks, hakates tähendama loomulikku kasvamist, unikaalse mina pidevat enesetäiustamist, oma võimete igakülgset väljaarendamist. Sellele eelneb indiviidi ainukordsuse idee: Herderi käsitluses on iga inimene ainulaadne, tal on olemas oma geneetiline jõud, tänapäevases sõnavaras geneetiline kood, mille järgi ta areneb, olles samal ajal avatud ka välistele jõududele (keskkonnamõjudele). Bildung tähendab kuju võtmist, endakssaamist, sisemistele geneetilistele võimetele vastavat arengut, mis toimub interaktsioonis ümbritseva maailmaga. See eeldab, et subjekt on välismaailmale avatud, aga ka seda, et maailmaga kohtuv subjekt on vaba otsustamaks, mis talle selle maailma pakutavast just sobib. Kujunev mina ei määratle end enam autoriteetide poolt ette antud mudelite kaudu, vaid tähelepanuvõime ja kriitilise refleksiooni kaudu. Selline Bildung eeldab subjektilt aktiivset hoiakut, kuid ka kujutlusjõudu, oskamaks anda enesekujundamisele sihti ja tähendust. Oma Bildung'i kallal tuleb vaeva näha: „Töötada oma moraalse arengu kallal, see on lihtsaim ja soovitatavaim asi, mida inimene võib ette võtta," kirjutab Goethe autobiograafias „Luulet ja tõtt“ (Goethe 1994: 88).

Indiviid võib end teadlikult kujundada üha täiuslikumaks - sellel veendumusel tugineb saksa klassikaline haridusideaal, millel põhines ka 1802. aastal taasrajatud Tartu ülikool. Wilhelm von Humboldti sõnul, keda peame ka Tartu alma mater'i ideoloogiks, on „inimese eesmärk oma jõudude ülim ja proportsionaalseim kujundamine tervikuks" (Humboldt 1851: 9), mis peab toimuma iseenda sisemiste võimete ja ümbritseva maailma loodud tingimuste koostoimes. Humboldtlikku haridusideaali kannab valgustuslik usk enesetäiustamise kaudu inimkonna täiustamisse, sest, nagu usuti Prantsuse revolutsiooni järgsel Saksamaal, individuaalne täiustumine, eneseharimine on ainus võimalus inimsoo edusammudeks. Otsustamaks inimese üle, on vaja küsida, millise sisu on ta osanud anda inimsuse vormile ning millist inimsuse mõistet võiks tema järgi kujundada.

Nii ütleb ka Wilhelm Meisteri üks õpetajaid, abbé: otsustamaks inimese üle, on tarvis huvi tunda tema hariduse/kujunemise (Bildung'i) vastu (Goethe 1958: 480).

Romaan, mis oli pööranud oma tähelepanu väliselt seikluslikkuselt „inimlikule loomusele“ (nii sõnastab oma „Tom Jones'i“ teema Henry Fielding), tegelase siseilmale, avastab, et see inimlik loomus pole midagi valmit, etteantut, vaid üha kujunev, ajas muutuv - narratiivne. Selle inimliku loomuse kujunemislugu, Bildungsgeschichte kujunes moodsa romaani teemaks. Juba Blankenburg, kes, analüüsides kaasaegseid romaane (Fieldingi, Sterne'i ja Wielandi omi 
- viimase „Agathoni lugu“ ilmus 1766/1767 ja seda loetakse esimeseks saksa kujunemisromaaniks), pani tähele nende romaanide ühist teemat: nad kujutavad peategelase vaimset ja moraalset arengut, tema teadvuse muutumist romaani jooksul. Romaani sihiks on peategelase iseloomu väljakujunemine, küpsuse saavutamine, mis tähendab tasakaalu leidmist mõistuse ja tunde vahel. Sealjuures on olulisem indiviidi kuuluvuse määraja tema haridus/ haritus, arenguvõimelisus, mitte seisus.

Morgenstern jätkab siit, saades tugineda juba arvukamatele saksa romaanidele, nende seas ka Goethe „Wilhelm Meisteri õpiaastatele“ (1795/1796), mis on tänini kujunemisromaani musternäidiseks.

Esmakordselt kasutab Morgenstern kujunemisromaani mõistet, kõneldes hoopis oma Tartu kolleegi, ülikooli kuraatori Friedrich Maximilian von Klingeri loomingust (loengus „Rea filosoofiliste romaanide vaimu ja seose üle“). Nähes kirjanikus tema kirjandusliku inimpildi peeglit, visandab ta Klingeri Bildungsgeschichte, mida näeb peegeldumas ka tema romaanikangelastes. Morgenstern esitab romaanikirjanikule kui isiksusele väga kõrgeid nõudmisi: "tõeline kirjanik peab olema tõeline inimene, või ta ei ole miski“ (Morgenstern 1817: 188). Vaid rikas elukogemus saab luua rikast loomingut. Ta imetleb Klingeri moraalset jõudu ja karakteri tugevust, mida tema looming ka lugejates kultiveerib, nähes seda just spetsiifiliselt saksa romaani omadusena. Niisiis on meil Morgensterni esimesest kirjutisest teada peamised kujunemisromaani tunnusjooned: romaan peab esitama kujunemislugu, mida kannustab indiviidi enesetäiustamistahe ning -võimelisus, et selle abil innustada ka lugejaid tööks iseenda moraalse arengu kallal.

Morgensterni edasistes käsitlustes on keskmes juba Goethe „Wilhelm Meisteri õpiaastad“, mida ta ei pea mitte niivõrd saksa, kuivõrd üleüldse „puhtinimliku kujunemise näidisteoseks“. „Kujunemisromaaniks, ütleme, võiks teda nimetada. Esiteks ja eeskätt aine pärast, kuna ta kujutab kangelase kujunemist, selle algust ja edenemist mingi küpsuse astmeni; teiseks aga ka, kuna ta just selle kujutamise abil edendab ka lugeja kujunemist laiemas ulatuses kui ükski teine romaanitüüp“ (Morgenstern 1820: 13), määratleb Morgenstern tema romaanitüpoloogias õilsaima romaanitüübi ülesande.

„Wilhelm Meisteri õpiaastad“ vastab sellele ülesandele, näidates „inimest, kes oma sisemiste eelduste ja väliste olude koosmõjul aegamisi loomupäraselt välja kujuneb“.

„Noorusest peale on mu hinges olnud ähmane soov kujundada enesest seda, kes ma tõesti olen" (Goethe 1958: 245), tunnistab Wilhelm Meister. Tema kujunemislugu on eneseleidmise lugu, oma tõelise mina äratundmine läbi eksimuste ja üha uue ümberkujunemise, pidevas dialoogis maailma ja selles kohatud inimestega, kes kõik vahendavad Wilhelmile (vastuolulisi) kogemusi ja tõekspidamisi, mille abil Wilhelm kujundab oma eluvormi, otsides „konsekventsust mitte asjaoludes, vaid iseeneses“.

Kujunemisromaani kangelane peab olema kujundatav, õpetab Morgenstern, ta peab olema kujunemisvõimeline, vormitav, plastiline, allumaks ümbritseva maailma kujundavale 
jõule. Samal ajal peab ta ise olema loominguline, et seda ümbritseva maailma kujundavat jõudu vastu võtta ja ära kasutada endale sobivas suunas. Vaid nii saab ta kujundada iseennast ja ühtlasi ka oma lugejat.

Kujunemisprotsessi siht on küpsuse, täiuslikkuse saavutamine - täiuslik tasakaal, harmoonia koos vabadusega. Wilhelm Meisteri lugu on autonoomse, vaba subjekti kujunemislugu - sellisena vist küll viimane maailmakirjanduse ajaloos. Saksa klassikaline idealism seadis utoopilise täiusetaotluse vastu modernse ühiskonna diferentseerumisprotsessile, otsides lepitust indiviidi ja ühiskonna vahel.

Pakkudes uue romaani žanrimääratluseks kujunemisromaani mõistet, talitab Morgenstern - klassikalise filoloogina - klassikalise humanismi vaimus. Aastal 1819, romantikute valitsemisajal, võis selline idealism tunduda juba üksjagu aegunud. Samal ajal kui Morgenstern Tartus, peab Berliinis loenguid esteetikast Friedrich Hegel, kes, küll kujunemisromaani mõistet kasutamata, kirjutab uute romaanide kangelastest nii:

Indiviididena on nad subjektiivsete taotlustega, mis puudutab armastust, au ja auahnust või oma maailmaparandamisideaalidega, vastandudes olemasolevale korraldusele ja tegelikkuse proosale, mis valmistab neile igast küljest raskusi. Selles vastuolus kerkivad subjektiivsed soovid ja nõuded mõõtmatuks; inimene avastab enda ees nõidusliku, talle täiesti ebasobiva maailma, millega tal tuleb võidelda, kuna see maailm paneb vastu ega anna oma tõredas kindlameelsuses järele tema kirgedele, tuues takistuseks isa või tädi tahte, kodanlikud olud vms. Nendeks uuteks rüütliteks on esmajoones noorukid, kes peavad läbi lööma maailma kulus, mis nende ideaalide asemel teostab iseend, ja kes peavad oma õnnetuseks, et neil on olemas perekond, kodanlik ühiskond, riik, seadused, elukutsed jne, sest need substantsiaalsed eluseosed oma piirangutega vastanduvad nii kohutavalt südame ideaalidele ja lõpmatule õigusele. Nüüd on tarvis lüüa mõra sellesse asjade korraldusse, muuta maailma, seda paremaks muuta või tema kiuste enesele vähemalt maapealne taevas välja lõigata: otsida endale tüdruk, nii nagu peab, leida ta, võita ta endale halbade sugulaste või muude ebasoodsate olude kiuste. Need võitlused pole aga moodsas maailmas midagi muud kui õpiaastad, indiviidi kasvatamine olemasoleva tegelikkuse tarvis, ja nad saavutavad nii oma tõelise tähenduse. Sest õpiaastate lõpp seisneb selles, et subjekt jookseb sarved maha, kohandab oma soovid ja arvamused olemasolevate olude ja nende mõistuspäraga, astub maailmaga suhtesse ja saavutab seal endale sobiva seisukoha. Olgu ta ükskõik kui palju maailmaga tülitsenud, selle lükatudtõugatud, - Iõpuks saab ta ikkagi oma tüdruku ja mingi ameti, abiellub, muutub kodanlaseks nii nagu iga teinegi: naine hoolitseb majapidamise eest, lapsedki ei jää tulemata, jumaldatud naine, kes alles oli see ainuke, ingel, osutub selliseks nagu teised, amet annab töö ja sekeldused, abielu koduorjuseks... ja nii on kassiahastus platsis. (Hegel 1984: 567.)

Hegeli iroonia tabab kujunemisromaani lõpplahendust: küpsuse saavutamine tähendab kohanemist „täiskasvanute maailmaga“ ehk siis olemasoleva korraldusega leppimist, kompromissi, konformismi. 
Aja jooksul on kujunemisromaanile kogunenud muidki etteheiteid, näiteks meestekesksus (juba Morgenstern rõhutas žanritunnusena „mehelik-moraalset mõttelaadi“ ning Hegelgi näeb romaanikangelastena üksnes noorukeid); eluvõõras idealism; küsitud on teleoloogilise ja utilitaristliku hariduskontseptsiooni suhte kohta võimuga ning pandud kahtluse alla koherentse identiteedi ülesehitamise võimalikkus. 20. sajand ei uskunud enam humaanse eksistentsi võimalikkusse ebahumaanses ühiskonnas. Sündisid pigem Antibildungsroman'id, nagu näiteks Robert Musili „Omadusteta mees“ või Günter Grassi „Plekktrumm“. Kui kujunemisromaan püüdis leida tasakaalu mõistuse ja tundeilma vahel, siis modernistlik romaan suunas oma freudistliku pilgu inimese teadvustamata, ratsionaalselt hoomamata poolele, esitades pigem mina lammutamist ning selle sidusaks looks jutustamise võimatust. Just see oli aga kujunemisromaani sisuks. Kuid ometi, olgu konstrueeritud või dekonstrueeritud, pole kujunemisromaani idee - mis inimene on ja mis ta olla võiks - ega ka tema usk ühiskonna paremaksmuutmise võimalusse inimese individuaalse arengu abil kuskile kadunud ja kujunemisromaane kirjutatakse üha. Tuleb vist nõustuda Morgensterniga - iga hea romaan on kujunemisromaan (Morgenstern 1824: 5).

\section{Valikbibliogra a fia}

Bakhtin, Mikhail 2002. The Bildungsroman and Its Significance in the History of Realism. Mikhail Bakhtin, Speech Genres \& Other Late Essays. Austin: University of Texas Press, pp. 10-57.

Castle, Gregory 2006. Reading the Modernist Bildungsroman. Gainesville: University Press of Florida.

von Goethe, Johann Wolfgang 1958. Wilhelm Meisteri õpiaastad. TIk L. Kibuvits. Tallinn: Eesti Riiklik Kirjastus.

von Goethe, Johann Wolfgang 1994. Aus meinem Leben. Dichtung und Wahrheit. Johann Wolfgang von Goethe, Werke. Bd. 10. Autobiographische Schriften II. (Hamburger Ausgabe.) München: Deutscher Taschenbuch Verlag.

Hegel, Georg Wilhelm Friedrich 1984. Ästhetik (1820/1835). Bd. 1. Berlin-Weimar: Aufbau.

von Humboldt, Wilhelm 1851. Ideen zu einem Versuch, die Grenzen der Wirksamkeit des Staats zu bestimmen. Breslau: Trewendt.

Jeffers, Thomas L. 2005. Apprenticeships: the Bildungsroman from Goethe to Santayana. New York: Palgrave Macmillan.

Kontje, Todd Curtis 1993. The German Bildungsroman: History of a National Genre. Columbia: Camden House.

Mayer, Gerhart 1992. Der deutsche Bildungsroman: von der Aufklärung bis zur Gegenwart. Stuttgart: J. B. Metzlersche Verlagsbuchhandlung.

Minden, Michael 2010. The German Bildungsroman: Incest and Inheritance. Cambridge: Cambridge University Press. 
Moretti, Franco 2000. The Way of the World. The Bildungsroman in the European Culture. London-New York: Verso.

Morgenstern, Karl 1817. Über den Geist und Zusammenhang einer Reihe philosophischen Romane. - Dörptsche Beyträge für Freunde der Philosophie, Literatur und Kunst III, S. 180-205.

Morgenstern, Karl 1824. Zur Geschichte des Bildungsromans. - Neues Museum der teutschen Provinzen Russlands, Nr. 1/1, S. 1-46.

Morgenstern, Karl 1820. Über das Wesen des Bildungromans. - Inländisches Museum, Nr. 1/2, S. 46-61; Nr. 1/3, S. 13-27.

Selbmann, Rolf 1984. Der deutsche Bildungsroman. Stuttgart: Metzler.

Summerfield, Giovanna, Lisa Downward 2009. New Perspectives on the European Bildungsroman. London-New York: Continuum. 